\title{
Temporal Trends of Dissolved Trace Metals in Jamaica Bay, NY: Importance of Wastewater Input and Submarine Groundwater Discharge in an Urban Estuary
}

\author{
Aaron J. Beck • J. Kirk Cochran • \\ Sergio A. Sañudo-Wilhelmy
}

Received: 15 October 2008 /Revised: 29 December 2008 /Accepted: 13 January 2009/Published online: 4 February 2009

(C) Coastal and Estuarine Research Federation 2009

\begin{abstract}
Jamaica Bay, NY, is a highly urbanized estuary within the boroughs of New York City conspicuously lacking published information on dissolved trace metal concentrations. The current study examines the distribution and cycling of trace metals in that embayment with data gathered during cruises in November 2004, April 2005, and June 2006. Most of the metal distributions (Fe, Zn, Co, Ag, $\mathrm{Cu}, \mathrm{Pb}, \mathrm{Ni}$ ) in the water column are explained by the input of substantial volumes of treated wastewater effluent. However, several lines of evidence suggest that submarine groundwater discharge (SGD) is also an important source of dissolved $\mathrm{Fe}, \mathrm{Zn}, \mathrm{Co}, \mathrm{Ni}$, and isotopically distinct stable $\mathrm{Pb}$ ratios $\left({ }^{206} \mathrm{~Pb},{ }^{207} \mathrm{~Pb},{ }^{208} \mathrm{~Pb}\right)$ in the Bay. Conversely, the recirculated seawater component of SGD is an apparent sink for dissolved Mo. This study provides the first measurements of dissolved trace metals in the Jamaica Bay water column and subterranean estuary and provides evidence for trace metal input due to SGD.
\end{abstract}

Marine Sciences Research Center contribution \#1380

A. J. Beck $(\bowtie) \cdot$ J. K. Cochran

Marine Sciences Research Center, Stony Brook University,

Stony Brook, NY 11794-5000, USA

e-mail: abeck@mpi-bremen.de

S. A. Sañudo-Wilhelmy

Department of Biological Sciences and Department of Earth

Sciences, University of Southern California,

Los Angeles, CA 90089-0371, USA

Present address:

A. J. Beck

Max Planck Institute for Marine Microbiology,

Celsiusstrasse 1,

28359 Bremen, Germany
Keywords Trace metals · Submarine groundwater discharge · SGD · Wastewater · Jamaica Bay · New York

\section{Introduction}

With the promulgation of the Clean Water Act in 1972, lawmakers sought to reduce the input of contaminants into US coastal waters. Although the legislation was successful in reducing point-source discharges of contaminants (US EPA 1995), it may not have resulted in significant reduction of trace metal levels in some estuaries (Sañudo-Wilhelmy et al. 2004). Some recent work has shown that a large portion of dissolved contaminant metal pools is currently attributable to nonpoint sources such as benthic remobilization (Sañudo-Wilhelmy and Gill 1999; Buck et al. 2005). In a similar manner, Gobeil et al. (2005) found that wastewater effluent contributed only a small portion of the total load for numerous trace metals in the St. Lawrence River estuary, although they could not definitively determine the identity of the dominant fluxes. However, Sañudo-Wilhelmy et al. (2004) note that some of our current inability to observe declines in contamination may simply be a lack of highquality trace metal data necessary for observing statistically significant trends. Additional data are necessary to assess the level of trace metal pollution in US coastal waters and identify potential nonpoint-source inputs.

Benthic trace metal release by diffusion from finegrained sediments is well-established (Aller 1994; Berelson et al. 2003). However, during the last decade, a large body of evidence has been gathered showing that advection of porewater through permeable sediments may also represent a major direct source of trace elements to coastal waters (Shaw et al. 1998; Charette and Buessler 2004; Bone et al. 2007; Windom et al. 2006). Considering the increasing 
volume of research confirming the large magnitude and global ubiquity of this submarine groundwater discharge (SGD), it is not unreasonable to expect that permeable sediments represent a significant trace metal source in both local and global budgets (Shaw et al. 1998; Charette and Sholkovitz 2006). Chemical transport by SGD is certainly not a geologically recent process [indeed, some researchers have inferred it from geologic records (e.g., Cochran et al. 2003)], but as anthropogenic activities modify the trace element composition of coastal marine sediments (Luoma and Phillips 1988), so also will they affect the composition of porewaters in contact with those sediments (Froelich et al. 1979; Shaw et al. 1990). Consequently, anthropogenic contamination of the sediments will affect the trace metal load transported in SGD, and as more data are collected, SGD will likely be implicated as a significant source of trace metals to coastal waters.

Therefore, the purpose of the present study is twofold: first, it establishes the first measurements of dissolved trace metals and stable lead isotopes in a heavily impacted urban estuary, Jamaica Bay, NY, and examines the cycling of metals in that system. Second, because trace metal samples were collected coincident with SGD tracers (i.e., naturally occurring radium isotopes), this study is also uniquely able to assess how SGD affects the dissolved trace metal composition of the water column.

\section{Study Site}

Jamaica Bay, NY, is a small $\left(\sim 52 \mathrm{~km}^{2}\right)$ estuary located within the confines of Brooklyn, one of the boroughs of New York City (Fig. 1). Jamaica Bay is a unique estuary in that the freshwater source is almost entirely anthropogenic, mainly treated wastewater effluent; there is no nonsewage surface input of fresh water (Houghton et al. 2005), and groundwater discharge supplies less than $10 \%$ of the fresh water flux (Misut and Voss 2004). Saline SGD, or recirculated seawater, in Jamaica Bay is $\sim 10$-fold higher than the fresh groundwater input, representing between 1.6 and $7.3 \times 10^{9} \mathrm{~L}$ day $^{-1}$, depending on the season (Beck et al. 2007a).

Four major and two minor wastewater treatment plants (WWTP) discharge effluent directly into Jamaica Bay (Benotti et al. 2006). The major WWTPs, Coney Island, Jamaica, 26th Ward, and Rockaway, discharge a combined average volume of about $9.8 \times 10^{8} \mathrm{~L} \mathrm{day}^{-1}$ of secondarytreated effluent. The locations of the outfalls of these WWTPs are shown in Fig. 1.

The bay is relatively shallow ( $<5 \mathrm{~m}$ depth), although some channels may be deeper. The deepest channels run along the western and southeastern borders of the bay. The residence time of water in Jamaica Bay has been estimated at 7-35 days (Houghton et al. 2005; Swanson et al. 1992),

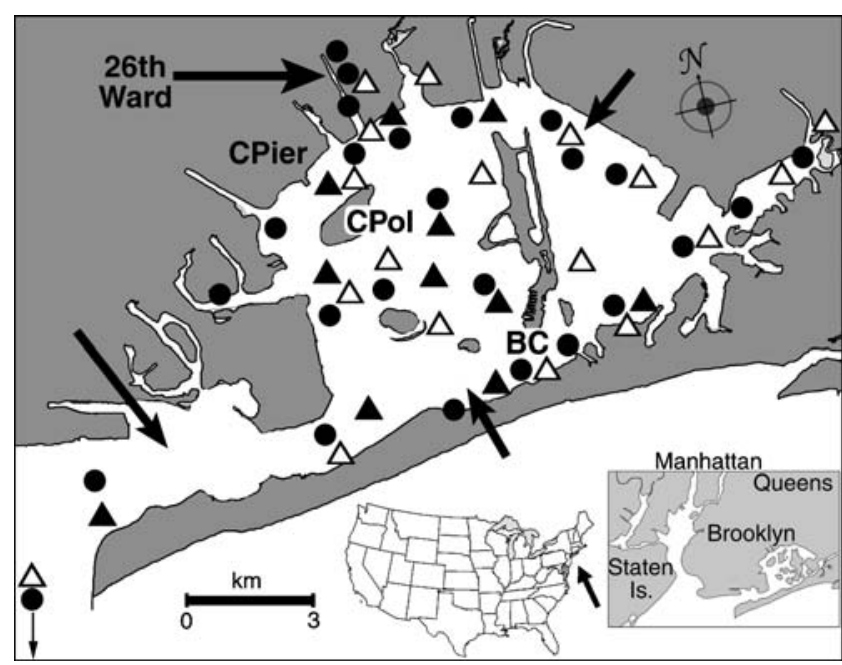

Fig. 1 Map of Jamaica Bay. Inset shows bay location relative to USA and New York City. Water column sample sites for all cruises are indicated; symbols indicate October 2004 (filled circles), September 2005 (filled triangles), and April 2006 (hollow triangles). Shallow groundwater sample sites are noted in large, boldface font; the site codes are Canarsie Pol $(\mathrm{CPol})$, Canarsie Pier (CPier), and Broad Channel $(B C)$. The large, boldface font label and arrow identify the location and effluent outfall of the 26th Ward WWTP. The approximate outfall locations of three other major WWTPs are indicated with large black arrows (Ferguson et al. 2001). John F. Kennedy International Airport is located at approximately the same point on the map as the direction compass. Note that extensive marshland exists in the bay but has been removed from this map for clarity (after Beck et al. 2007a)

and is shortest in these deep, well-flushed channels (R. Islieb, written communication, as cited in Benotti et al. 2006). Grassy Bay is a large, deep basin to the north, and restricted water flow results in a long residence time and seasonal hypoxia (Swanson et al. 1992). Grassy Bay is bordered to the north by John F. Kennedy International Airport, a major runway of which covers a substantial portion of former marshland (Bopp et al. 1993) and restricts water circulation through that portion of the bay (Swanson et al. 1992). To the northeast, limited flushing of the wide, shallow Thurston Basin also results in long residence time of the water (R. Islieb, written communication, as cited in Benotti et al. 2006).

Jamaica Bay is bisected by Rulers Bar Hassock, an island that supports a small residential population. There is extensive marshland in the center of the bay on either side of this central island, and the water depth is shallowest in this region of the bay. Extensive marsh loss has been documented for many marshes in Jamaica Bay during the past half-century (Hartig et al. 2002), although the exact reasons for this loss are unclear.

Trace metal data are lacking in Jamaica Bay. To our knowledge, only three peer-reviewed data sets of trace metals in Jamaica Bay have been reported (Ramondetta and Harris 1978; Seidemann 1991; Bopp et al. 1993), and all 
are measurements of sedimentary metal levels. In general, the sedimentary metal distributions in Jamaica Bay follow expected trends of covariation with grain size and organic carbon content; Grassy Bay and the interior marshes tend to have the highest metal concentrations (Ramondetta and Harris 1978; Seidemann 1991). Estimated metal fluxes to the bay show that the liquid sewage source is greatest, followed by raw sewage (combined sewage overflow, or CSO), atmospheric deposition, storm sewers, and landfill leachate (Seidemann 1991). Some data also suggest that trace metal inputs to Jamaica Bay have declined since the late 1960s or early 1970s, and storms and consequent CSO events can deliver large pulses of metal contaminants to the bay that are visible in the sedimentary record (Bopp et al. 1993).

\section{Materials and Methods}

\section{Water Column Samples}

Detailed information regarding the different cruises is available elsewhere (Beck et al. 2007a). Water sampling for trace metal analysis was conducted during three cruises in October 2004, September 2005, and April 2006. Water column conditions (e.g., temperature, dissolved oxygen, etc.) during the September and October cruises were characteristic of late summer, while the April cruise represented early spring conditions. Bay water samples for trace metal analysis were collected throughout the bay using clean techniques described in detail elsewhere (Flegal et al. 1991). Briefly, water samples were pumped onboard through acid-cleaned Teflon tubing using a peristaltic pump with clean C-Flex tubing in the pumphead. During October 2005 and April 2006, samples were collected from both surface ( 1 $\mathrm{m}$ depth) and bottom ( 1 $\mathrm{m}$ above sediment) depths. Water was filtered through an acid-washed $0.22-\mu \mathrm{m}$ calyx capsule filter directly into acid-washed 1-L lowdensity polyethylene bottles. Water samples were doublebagged in polyethylene bags and returned to the clean lab for processing. Dissolved organic carbon (DOC) samples were filtered in the same way, collected in precombusted glass bottles, and kept on ice until they could be frozen.

Samples for measurement of total dissolved trace metals were acidified to $\mathrm{pH}<2$ with Optima-grade $\mathrm{HNO}_{3}$, and stored for at least 1 month before extraction. Metals were then preconcentrated following the APDC/DDDC organic extraction of Bruland et al. (1985) and analyzed by ICP-MS (ThermoFinnigan Element2) using Indium as an internal standard. Trace elements in groundwater samples were directly analyzed by ICPMS after 20- or 40-fold dilution with ultrapure $1 \mathrm{~N} \mathrm{HNO}_{3}$. The uncertainty of trace metal measurements made on replicate field samples was generally less than 5\%, except for $\mathrm{Ag}(9 \%)$ and $\mathrm{Fe}$ and $\mathrm{Pb}(7 \%)$.
Blank levels were less than $5 \%$ of the lowest sample for all metals except Ag, for which blanks were approximately $20 \%$ of the sample concentrations.

Stable $\mathrm{Pb}$ isotope ratios were also measured by ICPMS in preconcentrated samples. Mass bias was corrected using the NIST 981 standard reference material (SRM) analyzed after every third unknown sample. Analysis of this SRM $(n=37)$ gave ratios of $2.1691 \pm 0.0065\left({ }^{208} \mathrm{~Pb} /{ }^{206} \mathrm{~Pb}\right)$ and $0.9136 \pm 0.0018\left({ }^{207} \mathrm{~Pb} /{ }^{206} \mathrm{~Pb}\right)$, compared to the certified values of $2.1681 \pm 0.0008\left({ }^{208} \mathrm{~Pb} /{ }^{206} \mathrm{~Pb}\right)$ and $0.91464 \pm$ $0.00033\left({ }^{207} \mathrm{~Pb} /{ }^{206} \mathrm{~Pb}\right)$.

DOC was determined by high-temperature catalytic oxidation (Sugimura and Suzuki 1988; Benner and Strom 1993). Salinity was measured with a YSI- 880 handheld probe. Chloride was analyzed by titration with $\mathrm{Ag}$ on a Radiometer Copenhagen CMT10 automatic chloride titrator.

\section{"Sewage Estuary"}

In order to understand the effect of sewage discharge on dissolved trace metal levels in the bay, we can examine the behavior of these constituents as they mix across the salinity gradient near a WWTP outfall. We have chosen the outfall from the 26th Ward WWTP, located at the northnorthwest border of the bay (Fig. 1). The treatment plant discharges its effluent (annual average discharge: 85 million gallons per day, or approximately 320 million liters per day) near the head of Hendrix Creek. Along the creek, well-defined quasiestuarine circulation is evident, with fresh effluent water exiting the creek in a shallow layer that overlays saltier water with approximately the same salinity as most of the bay. We refer to the mixing zone in this creek as the "sewage estuary." At the time of sampling in April 2006, the low-salinity (less than 10) surface layer was about $50 \mathrm{~cm}$ thick.

A five-point depth profile was sampled through this surface layer at approximately $10-\mathrm{cm}$ intervals in an attempt to obtain samples with a range of salinities. As shown in Fig. 3, the salinity gradient actually sampled was rather coarse, with four samples in the salinity range between eight and 11, and one sample with a salinity of 21 . With these, we include three surface water samples collected immediately before in the same vicinity; two of these samples were collected at the mouth of the creek and had salinities of 26-28. A sample with a salinity of six was collected near the WWTP outfall. The wastewater endmember sample collection is described below.

\section{Wastewater Effluent}

Filtered water samples were collected inside the 26th Ward WWTP on 8 February 2005. The samples were pumped from the holding tank immediately preceding the outfall 
canal. Three 1-L samples were collected across a 4.25-h time span at 11:45, 14:20, and 16:00 $\mathrm{h}$, and were processed as described for bay surface water.

\section{Groundwater}

Four shallow groundwater $(<4 \mathrm{~m}$ depth $)$ profiles were collected at three locations in the bay (Canarsie Pol, Canarsie Pier, Broad Channel; Fig. 1). Sample sites were chosen because they represent some of the most expansive sandy beaches in the bay. Groundwater advection through permeable sediments has been shown to be a major process in Jamaica Bay (Beck et al. 2007a), and groundwater profiles were collected at the presumed sites of discharge. Canarsie Pier is located on the northwestern mainland side of the bay, while Broad Channel is located on the southern end of the large, developed island in the center of the bay. Canarsie Pol is a large, undeveloped island in the northwest corner of the bay; this island is surrounded mostly by sandy shores, stands well above sea level, and is covered by dense thickets of large trees.

Shallow groundwater profiles were sampled using a stainless steel Retract-a-Tip (AMS) drive-point piezometer with acid-washed Teflon tubing (Charette and Sholkovitz 2006; Charette and Allen 2006). Before collecting a sample at each depth, enough water was purged to flush the volume of the sampling system three times. Small-volume samples (60-250 mL) were either pump-filtered through $0.22 \mu \mathrm{m}$ polypropylene Calyx capsule filters or syringe-filtered using $0.45 \mu \mathrm{m}$ nylon filters. Sufficient sample was flushed through the filter before each collection to prevent artifacts associated with changing the redox characteristics of the sample (Bray et al. 1973; Lyons et al. 1979).

\section{Results and Discussion}

Distribution of Dissolved Trace Metals in the JB Water Column

The trace metal distribution with salinity in the JB water column is shown in Fig. 2. Samples with salinities below 20 have been excluded from these graphs because, during five cruises in Jamaica Bay (trace metal data exist for only three of these cruises), we have only observed substantially decreased salinities within the creek that receives effluent from the 26th Ward WWTP. As we have already discussed those data in detail, we exclude them to improve the clarity of the high-salinity graphs.

For nearly all elements, the salinity distributions show differences between cruises, with the highest metal concentrations observed in April 2006, intermediate levels in October 2004, and lowest levels measured in September
2005. However, little difference was observed between the September and October cruises for $\mathrm{Fe}$ and $\mathrm{Pb}$ (Fig. 2a, g). The greatest difference between April and September cruises was observed for $\mathrm{Mo}, \mathrm{Zn}$, and $\mathrm{Fe}$, which were higher in April by factors of approximately 1.5, 5, and 5, respectively. Taking the measured effluent concentrations as the correct or "true" fresh endmember, nearly all metals showed removal relative to conservative mixing, except during the April cruise, when nonconservative input of $\mathrm{Co}$, $\mathrm{Cu}$, and $\mathrm{Fe}$ was evident and $\mathrm{Ni}$ appeared to be approximately conservative.

This apparent nonconservative input of $\mathrm{Cu}$ and $\mathrm{Co}$ (Fig. 2e, c) is somewhat problematic in that data from the sewage estuary indicated that these elements were removed during mixing with bay water (discussed below; Fig. 3e, c). Maximum water temperatures in April were approximately $10^{\circ} \mathrm{C}$, whereas temperatures during the summer cruises were typically greater than $22^{\circ} \mathrm{C}$; because of the temperature-dependence and seasonal patterns of diffusive (Aller 1994) and SGD (Beck et al. 2007a) fluxes, it is unlikely that the nonconservative excess of these metals during April is due to diagenetic remobilization and benthic input. Thus, the apparent input observed during the April cruise probably results from variability in the wastewater endmember.

For the sewage estuary discussed above, close spatial proximity of the samples indicates probable influence only from the observed wastewater and bay water endmembers. However, the remainder of the bay also receives effluent from three other major WWTPs. Because of this, apparent nonconservative input likely reflects variable endmember concentrations and the fact that Jamaica Bay is not a simple two-endmember system. In reality, each WWTP may discharge water with a unique trace metal signature. An accurate mass balance for trace metals in Jamaica Bay would probably require monitoring of individual wastewater inputs.

\section{Covariation of $\mathrm{Cu}, \mathrm{Ni}$, and $\mathrm{Zn}$ with $\mathrm{DOC}$}

DOC data only exist for the September 2005 cruise, when the lowest dissolved metals levels were observed (Fig. 2). During that cruise, $\mathrm{Cu}, \mathrm{Ni}$, and $\mathrm{Zn}$ showed strong covariation with DOC (Fig. 4). The good correlation between the metals and organic carbon suggests that organic complexation was a significant process regulating the solubility of $\mathrm{Cu}, \mathrm{Ni}$, and $\mathrm{Zn}$ in Jamaica Bay, perhaps resulting from the input of strong organic ligands from wastewater (Sedlak et al. 1997).

Although all three of these metals exhibited a positive correlation with $\mathrm{DOC}$, the intercepts of the trends differ. $\mathrm{Ni}$ and $\mathrm{Cu}$ both showed positive $\mathrm{y}$-intercepts, suggesting that DOC was not the only factor affecting the geochemical 
Fig. 2 Trace metal vs salinity plots. Because the bulk of the water column samples have high salinity, the $\mathrm{x}$ axis has been cropped to exclude salinities less than 20 (see Fig. 3). Solid square symbols indicate October 2004 cruise, hollow circles indicate September 2005 cruise, and hollow triangles indicate April 2006 cruise. Solid lines represent theoretical conservative mixing between wastewater $(S \sim 0)$ and coastal ocean endmembers $(S=31)$
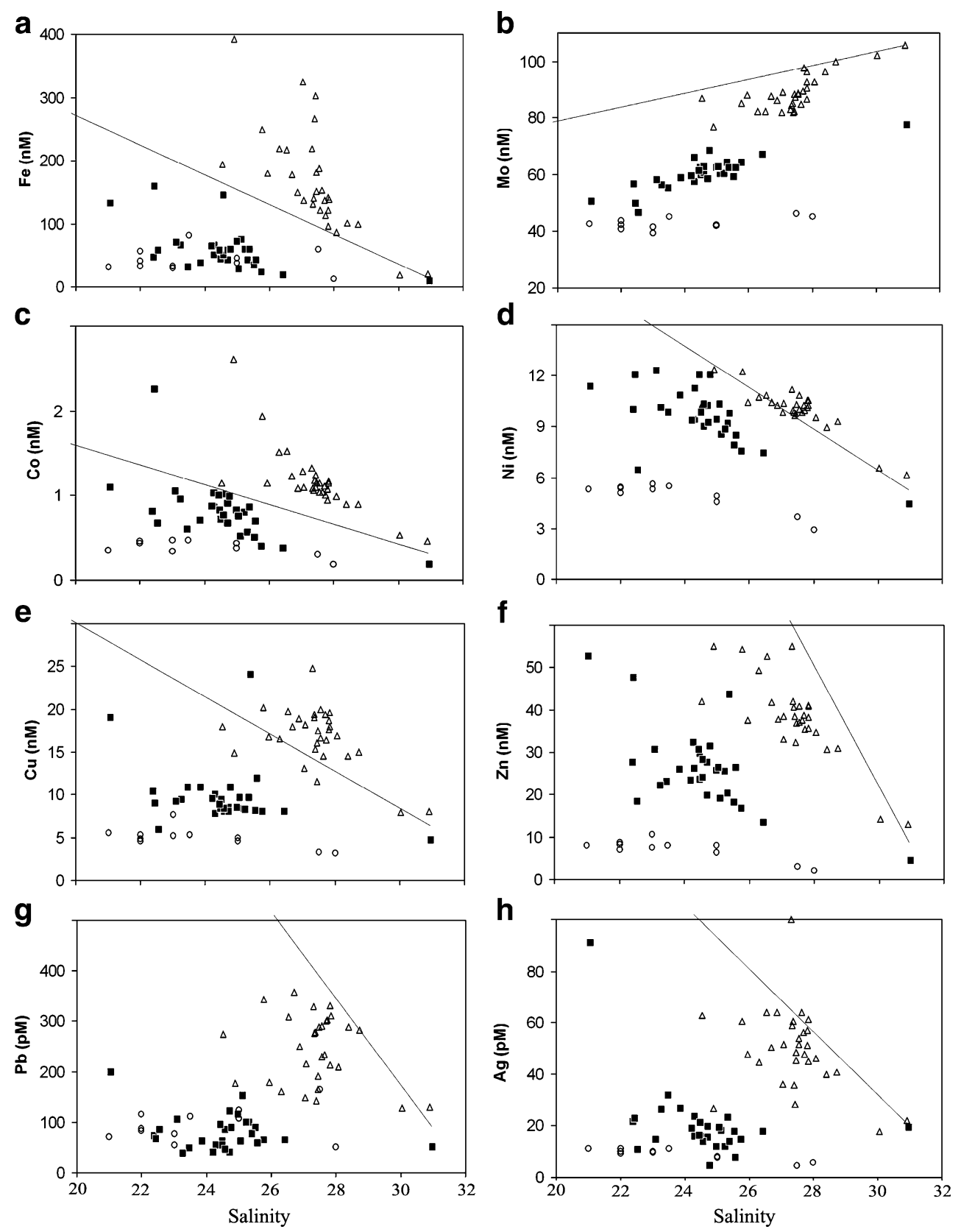

cycling of these metals in the dissolved phase. Conversely, the negative intercept observed for $\mathrm{Zn}$ implies that DOC may be the most important variable for maintaining the elevated concentrations observed in the Jamaica Bay water column.

\section{Behavior of Dissolved Trace Metals in the Sewage Estuary}

The samples collected in the "sewage estuary" will be used to examine the behavior of dissolved trace metals during the mixing of sewage effluent and bay water. In this case, we assume that the WWTP samples collected in February 2005 are representative of that endmember during April 2006, and that the 26th Ward WWTP is the primary source of fresh water to this local region of the bay.
The data showed relatively coherent trends for the different trace metals (Fig. 3). Dissolved $\mathrm{Mo}$ and $\mathrm{Fe}$ appeared to be mixed conservatively with respect to salinity (although the trends are inverse), while $\mathrm{Co}, \mathrm{Pb}$, and $\mathrm{Zn}$ showed pronounced removal. For $\mathrm{Ag}, \mathrm{Ni}$, and $\mathrm{Cu}$, the trend is less clear due to variability in the fresh (sewage) endmember. For each of these elements, two of the WWTP samples were similar to within about $10 \%$, while the third differed from the other two by $25 \%$ to $50 \%$ (e.g., Ag: 452 , 493 , and $245 \mathrm{pM}$ ). Because of this, the trends can be interpreted either as nearly conservative or as nonconservative removal. We cannot definitively identify the source of this variability, although it may simply suggest that dissolved metal concentrations in the wastewater plant are 
Fig. 3 Distribution of dissolved trace metals in the mixing zone, or "sewage estuary," near the 26th Ward WWTP outfall. Symbol shapes are as follows: crosses indicate 26th Ward wastewater samples (collected February 2005), hollow triangles indicate surface water samples in the vicinity of the outfall creek (collected April 2006), and solid circles indicate samples collected in a shallow surface profile (collected April 2006; see text for explanation). The solid line represents conservative mixing between endmembers of wastewater at the head and bay water at the mouth of the creek. The dashed line indicates an approximate best fit through the bay water and sewage estuary samples, excluding the wastewater endmember
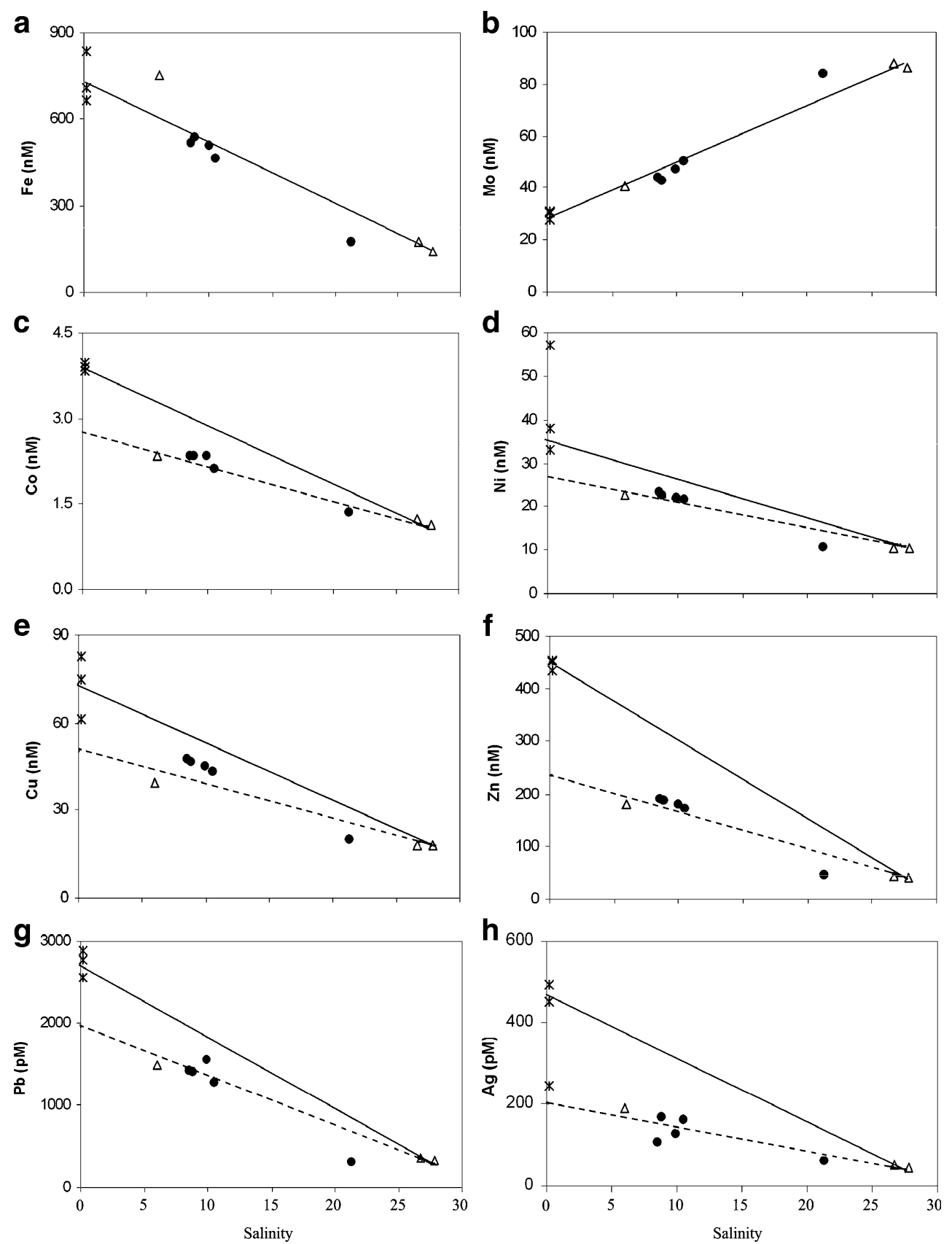

not at steady state, the water in the holding tank is not well mixed, and/or that there is diel variability in the chemical composition of municipal influent (Gobeil et al. 2005; Ternes and Hirsch 2000; Benotti 2006).

For Ag, the dominant process was probably removal, owing to its particle-reactive nature and usual similarity in distribution to $\mathrm{Pb}$ (Sañudo-Wilhelmy and Flegal 1992). Indeed, the general constancy of the $\mathrm{Pb} / \mathrm{Ag}$ ratio at a value of about seven across the mixing zone suggests similarity in the cycling of these two elements. In fact, the molar ratios throughout the bay tended to be relatively high, averaging $6.2 \pm 4.6 \mathrm{~Pb} / \mathrm{Ag}$ throughout all three cruises (as compared to $\mathrm{Pb} / \mathrm{Ag} \sim 3$ reported by Sañudo-Wilhelmy and Flegal 1992).
These high ratios may suggest that the Ag content of wastewater has declined during the time since the SañudoWilhelmy and Flegal report.

Dissolved $\mathrm{Ni}$ and $\mathrm{Cu}$ (Fig. 3d, e) exhibited relatively similar trends, although there was one high Ni measurement observed in the wastewater endmember $(57 \mathrm{nM})$. This one elevated sample suggests substantial $(>50 \%)$ removal of $\mathrm{Ni}$ in the sewage estuary. However, if the other data are more representative of the true end-member, then both $\mathrm{Cu}$ and $\mathrm{Ni}$ exhibited only slight removal (less than 30\%) relative to conservative mixing between the endmembers.

Nonconservative removal appears to be most substantial in the region where salinity is less than five, as metal 


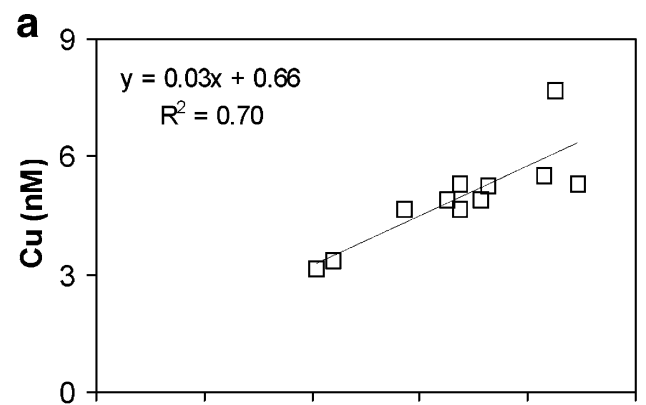

b
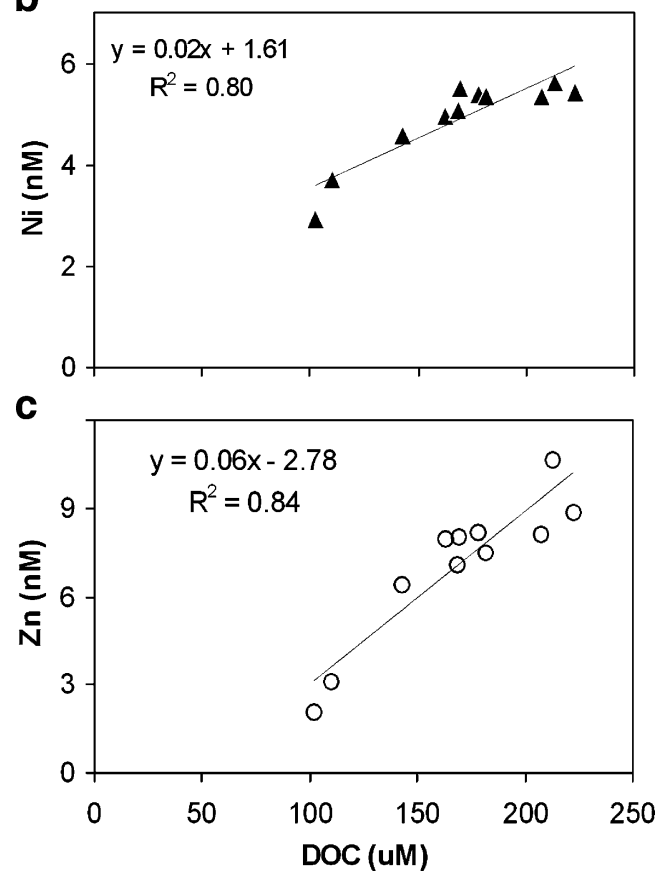

Fig. 4 Covariation of $\mathrm{DOC}$ and $\mathbf{a} \mathrm{Cu}, \mathbf{b} \mathrm{Ni}$, and $\mathbf{c} \mathrm{Zn}$. The straight line, equation, and correlation coefficient represent a linear regression of the data

concentrations were approximately linear at higher salinities. The degree of removal can be estimated as the difference between the concentration measured in the effluent and the concentration calculated for $S=0$ by extrapolation of a regression line drawn through the approximately linear portion of the data. Following this approach, the degree of removal ranges from $\sim 23 \%$ for $\mathrm{Ni}$ to $58 \%$ for Ag (Table 1).

The fact that all of these metals showed removal below a salinity of five and relatively linear trends at salinities between five and 27 suggests that a portion of the metal pool in the wastewater is relatively more labile or particlereactive, and that this fraction is removed rapidly upon mixing with bay water. This is consistent with previous studies of sewage-impacted estuaries, with much of the wastewater metal load removed from the dissolved pool within the estuary and not exported to the coastal ocean (Gobeil et al. 2005). The remaining portion of the dissolved metal pool is more stable or refractory and tends to behave conservatively during mixing. The low degree of removal calculated for $\mathrm{Cu}$ and $\mathrm{Ni}$ ( $30 \%$ and $23 \%$, respectively) is consistent with previous work showing that these metals tend to be strongly complexed with anthropogenic organic ligands in wastewater (Sedlak et al. 1997). On the other hand, the conservative mixing behavior of $\mathrm{Fe}$ in the sewage estuary contrasts starkly with the nearly quantitative removal commonly observed in river estuaries (e.g., Boyle et al. 1974; Sholkovitz et al. 1978). This is likely due to different flocculating agents in wastewater and river water; in riverine systems, coagulation of humic substances is responsible for the Fe removal, and wastewater effluent has much lower humic content (Ma et al. 2001).

Dissolved Trace Metals in the Jamaica Bay Subterranean Estuary

As described in the "Materials and Methods" section, four depth profiles of shallow ( $<400 \mathrm{~cm}$ depth) groundwater were collected from three different locations across the bay (Fig. 1). Concentrations of dissolved trace metals in Jamaica Bay groundwater were highly variable and had vertical structures indicative of diagenetic processes and redox zonation (Fig. 5). Although several of the stations did show a decline in salinity with depth, the minimum salinity observed was still higher than six (i.e., $\mathrm{Cl}^{-} \sim 90 \mathrm{mM}$; Fig. 5). In general, metal concentrations were highest in the upper $150 \mathrm{~cm}$, although the deepest profile shows that some metals were most greatly enriched below $200 \mathrm{~cm}$. Levels of dissolved metals in the very shallowest layer tended to be lower than those directly below (Fig. 5), and this can also be seen in the relatively low concentrations observed at high salinities (Fig. 6). The apparent remobilization of metals in the upper layers of the sediment suggests that geochemical processes in the more saline region of the subterranean estuary may increase SGD metal fluxes; however, the low concentrations observed directly at the sediment-water interface are indicative of metal removal

Table 1 Percent removal of trace metals in the sewage estuary due to nonconservative mixing trends with salinity

\begin{tabular}{lccc}
\hline & $\mathrm{C}_{\mathrm{ww}}(\mathrm{nM})$ & $\mathrm{C}^{*}(\mathrm{nM})$ & \% Removal \\
\hline $\mathrm{Ag}$ & 0.475 & 0.2 & 58 \\
$\mathrm{Co}$ & 3.9 & 2.8 & 28 \\
$\mathrm{Cu}$ & 73 & 51 & 30 \\
$\mathrm{Fe}$ & 735 & 735 & 0 \\
$\mathrm{Mo}$ & 28 & 28 & 0 \\
$\mathrm{Ni}$ & 35 & 27 & 23 \\
$\mathrm{~Pb}$ & 2.75 & 2 & 27 \\
$\mathrm{Zn}$ & 450 & 235 & 48 \\
\hline
\end{tabular}

These values are estimated from Fig. 3.

$C_{w w}$ actual wastewater endmember, $C^{*}$ apparent freshwater concentration based on extrapolation of a straight line drawn through the linear portion of the most saline data points (see text) 


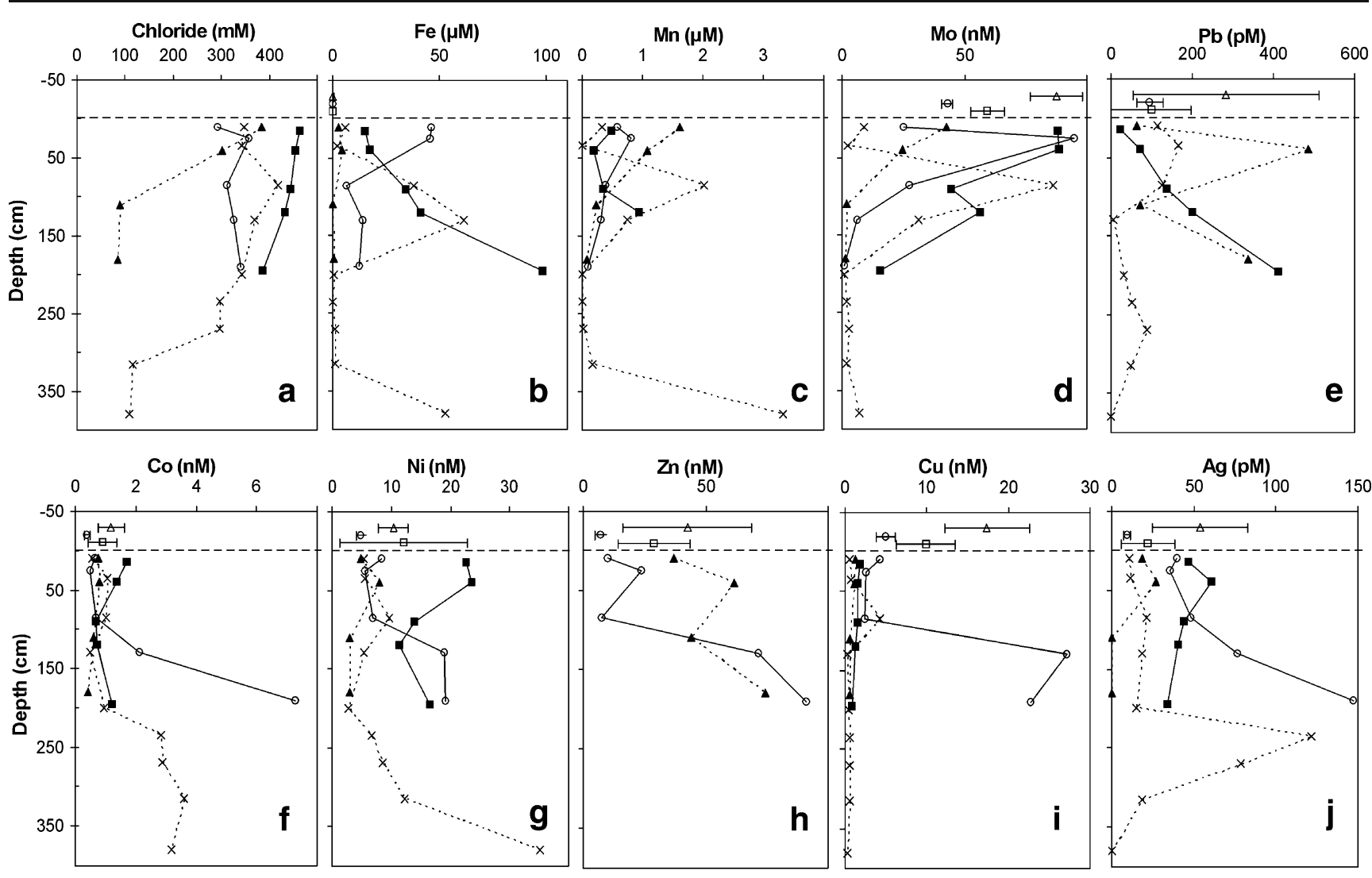

Fig. 5 Depth profiles of $\mathbf{a}$ chloride and $\mathbf{b}-\mathbf{j}$ trace metals in groundwater. The dashed horizontal line represents the sedimentwater interface (SWI), with positive depths directed into the sediment. Porewater symbols represent: hollow circles, Canarsie Pier, March 2006; solid squares, Canarsie Pol, May 2006; asterisks, Canarsie Pier,
May 2006; solid triangles, Broad Channel, November 2006. Hollow symbols above the SWI show the average and standard deviation of concentrations measured in the water column during the three cruises: squares are October 2004, triangles are September 2005, and circles are April 2006

Mn concentrations peaked at a higher salinity than did $\mathrm{Fe}$ (Fig. 6a, b). It is not entirely clear what process is responsible for the enrichment of both metals in the upper $1.5 \mathrm{~m}$ of the sediment, although diagenesis and remobilization from solid oxide phases is quite likely important (Froelich et al. 1979; Shaw et al. 1990; Aller 1994). Given the high surface reactivity and scavenging potential of solid Mn- and Fe-oxides, elevated levels of other trace metals in this shallow groundwater may result from release during $\mathrm{Mn}$ and $\mathrm{Fe}$ cycling. However, the lack of clear patterns of covariation suggests that metal geochemistry in Jamaica Bay groundwaters is more complicated than this process alone can explain.

At the Canarsie Pier location in March 2006, dissolved Mo showed a pattern of depletion at the surface, remobilization and increase at $100 \mathrm{~cm}$, decrease to nearly zero between 200 and $300 \mathrm{~cm}$, and a small increase at $400 \mathrm{~cm}$ (Fig. 5d). Although the magnitudes are different, this pattern generally follows the trends of dissolved $\mathrm{Mn}$ (Fig. 5c), indicating that Mo may be affected by scavenging onto Mn-oxides, and is returned to solution when the oxides are dissolved (Shaw et al. 1990). The same 

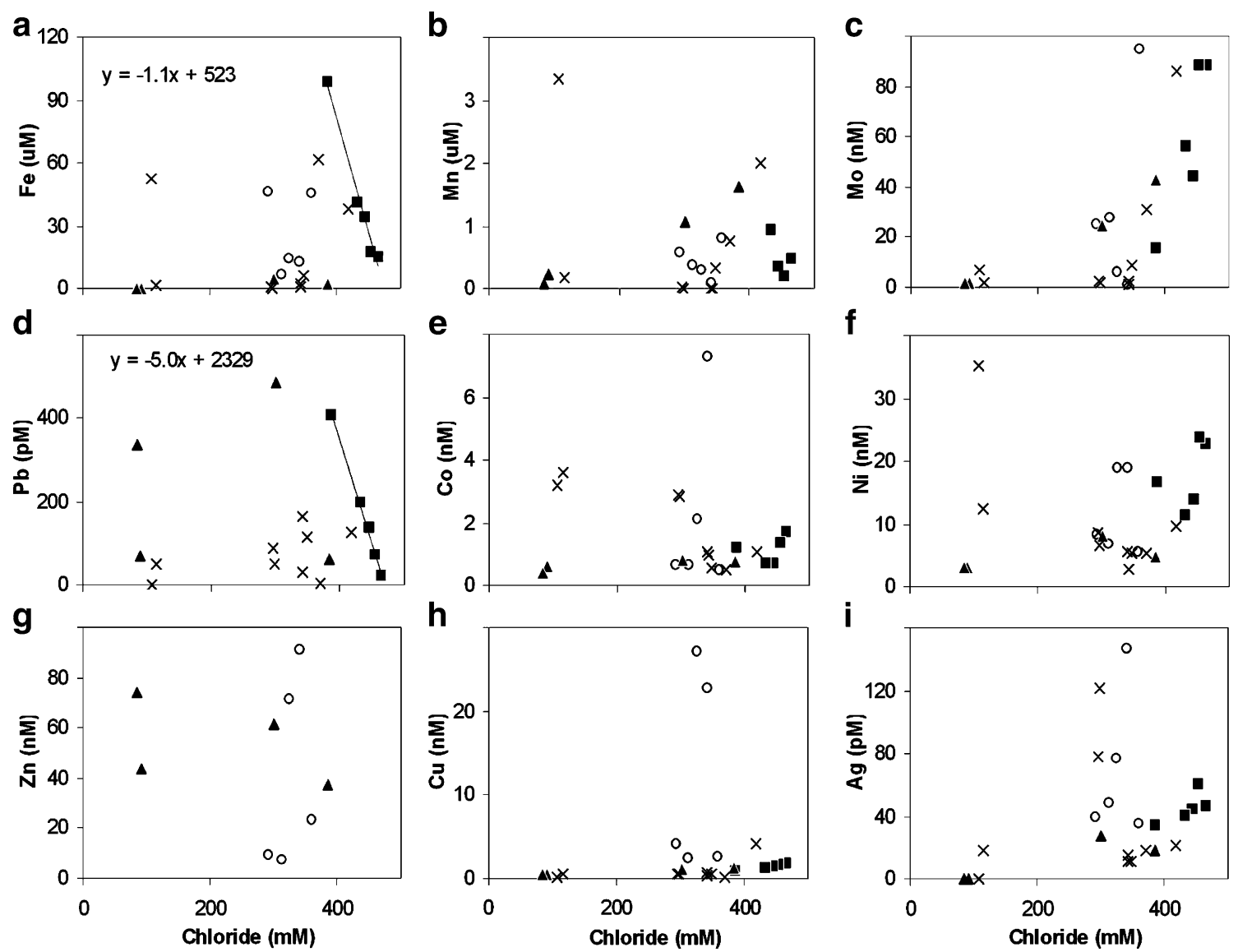

Fig. 6 Dissolved metals in shallow $(<4 \mathrm{~m}$ depth) groundwater. Different symbols correspond to different sampling locations, and are the same as those in Fig. 5. The lines and equations shown in the Fe and $\mathrm{Pb}$ plots represent linear regression of the most saline samples;

argument appears to hold for the other Canarsie Pier (March 2006) and Broad Channel (November 2006) profiles, although it is less clear in the Canarsie Pol (May 2006) data (Fig. 5).

\section{Other Metals}

The Ni profiles generally show similar behavior to Mo (as with $\mathrm{Mn}$ and Mo, there is not a direct correlation, but trends in concentration with depth match fairly well for these elements), consistent with previously reported variation between $\mathrm{Mn}$ and $\mathrm{Ni}$ in the subterranean estuary (Beck et al. 2007b). However, in that same study (West Neck Bay, NY), Co also covaried with $\mathrm{Mn}$. In Jamaica Bay groundwaters, Co appears to be decoupled from Mn cycling (Fig. 5f). In West Neck Bay (Beck et al. 2007b), Co was also observed to covary with DOC. Thus, it may be reasonable to again invoke DOC (Shafer et al. 2004) to also explain the Co profiles. To some degree, the $\mathrm{Pb}$ profiles (particularly May 2006) match the trends observed for Co (Fig. 5e), and the two may be cycled in a similar manner. such regression lines can be used to estimate effective zero-salinity endmember concentrations (see text), but only work well for these two elements

Dissolved Zn was below our detection limit in two of the profiles (both March 2006), but where it was measurable, the trends suggested that it may be cycled similarly to Co (Fig. 5h). In general, the measurable levels of $\mathrm{Zn}$ were the same or slightly higher than in the water column. Thus, similar to $\mathrm{Fe}$, which was also elevated in the porewater relative to the overlying water, advection of these porewaters out of the sediment could represent a source of $\mathrm{Zn}$ to the bay.

Except for one profile (Canarsie Pier, March 2006), dissolved $\mathrm{Cu}$ in the subterranean estuary was much lower than observed in the water column (Fig. 5i). This suggests that recirculation of seawater through the sediments may represent a sink for $\mathrm{Cu}$ in Jamaica Bay. This contrasts the results of Charette and Buessler (2004), who showed that SGD was a source of $\mathrm{Cu}$ to the Elizabeth River (Virginia). The mechanisms regulating sequestration or remobilization may be different between Jamaica Bay and the Elizabeth River, and further work is needed to clarify the issue.

Dissolved $\mathrm{Ag}$ and $\mathrm{Pb}$ profiles were quite variable, depending on the location and time of sampling (Fig. $5 \mathrm{~g}$, e), and factors causing the variability cannot be conclusively 
determined. In some instances, the porewater concentrations were higher than the water column, while in other cases, the levels were lower in the porewater. This suggests that SGD may represent either a source or a sink for these metals, depending on the location of recirculation and discharge.

\section{Identification of Trace Metal Sources to Jamaica Bay}

\section{Element-Element Plots}

To further support the input of metals due to SGD, metalmetal plots can be used to identify different sources (e.g., Paulsen 2005). Because covariation with Ra suggests that Co and $\mathrm{Zn}$ have an SGD source, these two metals may be the best tracers. In addition, their distribution in the sewage estuary showed strong removal of both $\mathrm{Zn}$ and Co from wastewater during mixing with bay waters. Thus, the wastewater signature will be slightly diminished, allowing the SGD input to be better distinguished.

Figure 7 shows a plot of dissolved $\mathrm{Zn}$ vs Co in the Jamaica Bay water column. The wastewater samples are clearly distinguishable with high Co and $\mathrm{Zn}$ levels, and samples in the sewage estuary fall on a mixing line between bay samples and this wastewater endmember. The bulk of the bay water samples fall on a mixing line between the inlet and the most saline samples at the mouth of the sewage estuary. The different slopes between the samples from the sewage estuary and those in the bay water column suggest that the removal of $\mathrm{Zn}$ and Co occurs primarily within the sewage estuary. Thus, after the water is mixed to a salinity greater than about 20 , the $\mathrm{Co}-\mathrm{Zn}$ ratio is relatively constant. This results in an apparent intermediate endmember, such that ocean water and effluent water both mix with a secondary bay water endmember.

A third endmember is evident with high dissolved Co concentrations relative to $\mathrm{Zn}$ (Fig. 7). The samples farthest from the sewage estuary mixing line are from Thurston Basin, the large semienclosed basin at the northeast corner of the bay (Fig. 1). This is the location where some of the highest dissolved Ra activities in Jamaica Bay have been observed (Cochran et al. 2006), suggesting that it is a region of significant SGD input. Indeed, groundwater modeling has indicated that much of the groundwater discharge to Jamaica Bay occurs in the region near Thurston Basin (Misut and Voss 2004). Furthermore, that this basin is far from any of the major WWTP point-source inputs suggests that the possibility of a second unique wastewater signature cannot account for this deviation from the other bay samples.

\section{$\mathrm{Pb}$ Isotope Ratios as an Indicator of Pb Sources}

$\mathrm{Pb}$ isotope ratios have been widely utilized to identify sources of $\mathrm{Pb}$ (e.g., Stukas and Wong 1980; Sañudo-

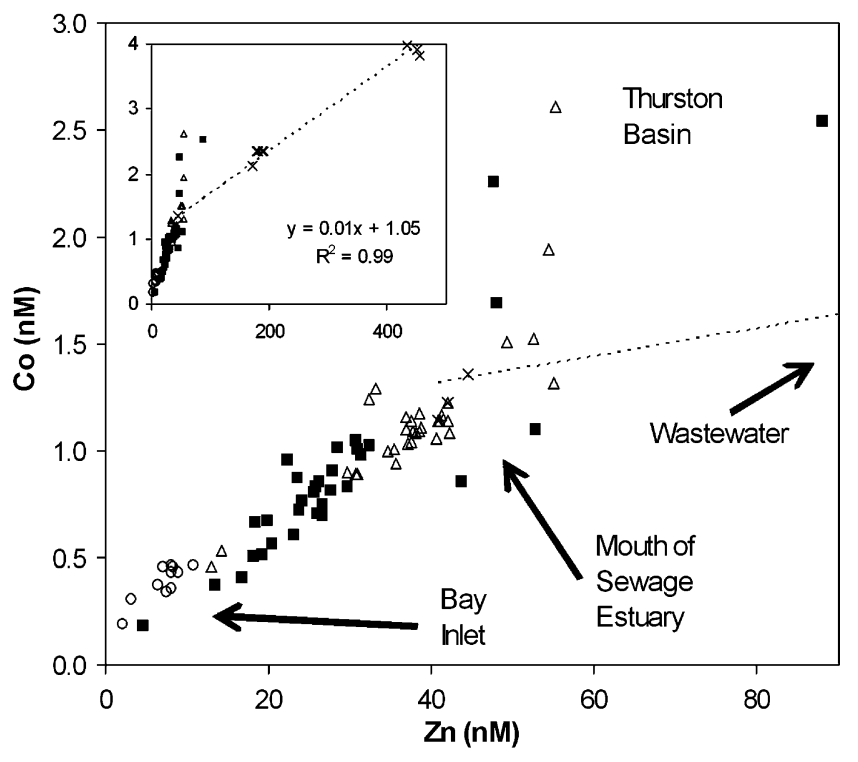

Fig. 7 Water column dissolved Zn vs Co. The inset shows all samples, while the larger graph provides an expanded view near the origin for clarity. Symbols are the same as in Fig. 2, except the $x$ shaped symbols indicate effluent and sewage estuary samples here. The dashed line and equation in the inset represent a linear regression of the sewage estuary data points

Wilhelmy and Flegal 1994). In the Jamaica Bay water column, there is a consistent trend between ${ }^{207} \mathrm{~Pb} /{ }^{206} \mathrm{~Pb}$ and ${ }^{208} \mathrm{~Pb} /{ }^{206} \mathrm{~Pb}$ (Fig. 8a). $\mathrm{Pb}$ isotope ratios in the wastewater effluent tend to have relatively low ${ }^{208} \mathrm{~Pb}$ and ${ }^{207} \mathrm{~Pb}$ relative to ${ }^{206} \mathrm{~Pb}$, as do samples from the sewage estuary. Samples collected outside the Jamaica Bay inlet have ${ }^{207} \mathrm{~Pb} /{ }^{206} \mathrm{~Pb}$ ratios of approximately 0.845 and ${ }^{208} \mathrm{~Pb} /{ }^{206} \mathrm{~Pb}$ ratios of 2.06-2.07. Most of the bay water samples have $\mathrm{Pb}$ ratios that plot between these two endmembers.

However, many of the water column samples, particularly those collected during the October 2004 cruise, plot outside of the inlet and wastewater endmember range. The sample with the highest ${ }^{207} \mathrm{~Pb} /{ }^{206} \mathrm{~Pb}$ ratio also has high $\mathrm{Ra}$ activities, suggesting that it reflects groundwater input. In fact, samples farthest from the effluent-inlet mixing line and with the most radiogenic signature (Fig. 8a) were collected in the western region of the bay, where the spatial distribution of Ra has indicated high SGD input (Cochran et al. 2006). Furthermore, there is a positive relationship between ${ }^{207} \mathrm{~Pb} /{ }^{206} \mathrm{~Pb}$ and ${ }^{223} \mathrm{Ra}$, indicating an SGD source of $\mathrm{Pb}$ with a more radiogenic signature (Fig. 9).

Comparing the $\mathrm{Pb}$ ratios measured in the Jamaica Bay water column with reported values for the NY and Hudson River region gives some indication as to the $\mathrm{Pb}$ sources in the bay. Figure $8 \mathrm{~b}$ is a plot that includes $\mathrm{Pb}$ ratios from possible sources. The relatively low ratios measured in wastewater and the sewage estuary correspond fairly well with anthropogenic, atmospheric $\mathrm{Pb}$ ratios (Marcantonio et al. 2002). Additionally, these ratios tend towards the low 

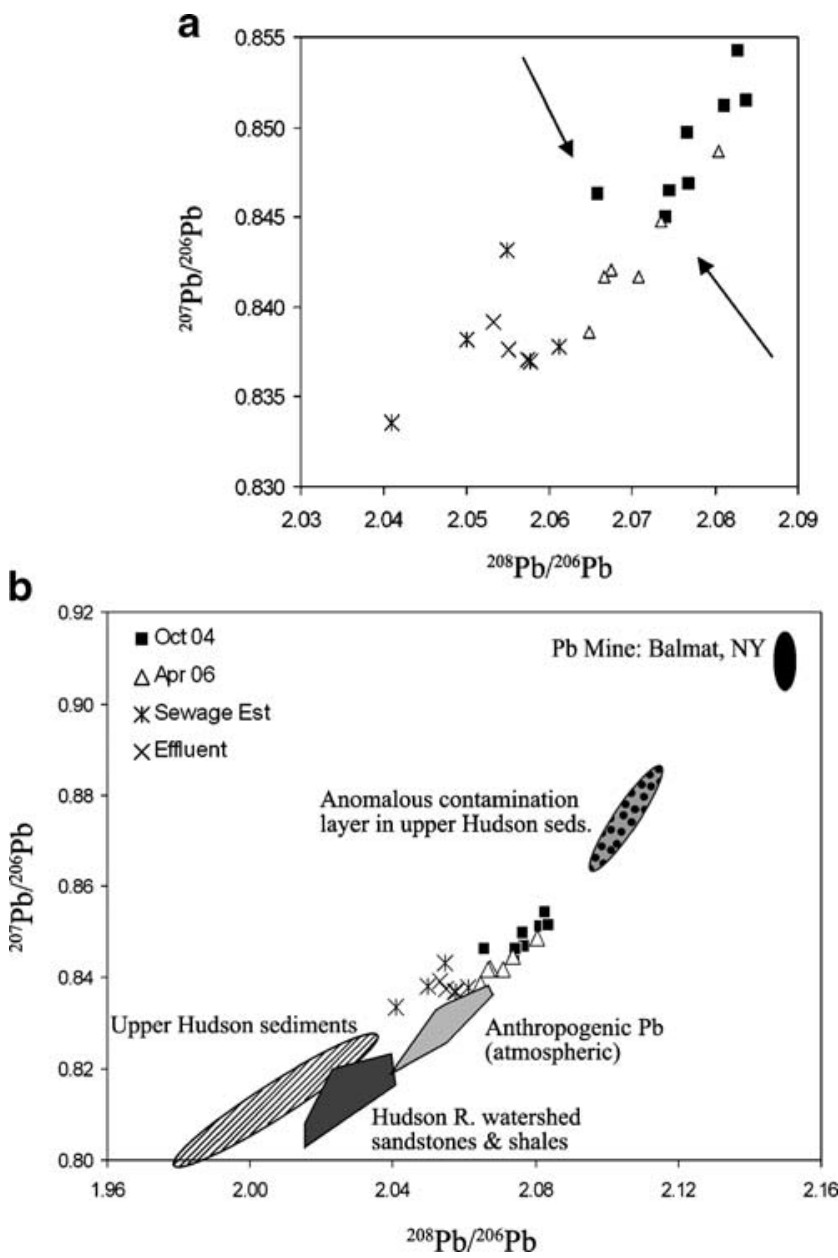

tion from a local pigment factory, one that probably would have used local $\mathrm{Pb}$ from a mine in Balmat, NY. This is relevant here because a $\mathrm{Pb}$ smelter was operated for several decades at the turn of the twentieth century in Jamaica Bay, processing as much as 4,000 tons of ore annually (Black 1981). The smelter location was Mill Island, now obscured under artificial fill (Englebright 1975) near the present-day Canarsie Pier (Fig. 1). This is one location where Ra distributions have indicated a particularly large source of SGD (Cochran et al. 2006). Black's references are somewhat obscure (historical town records), so we cannot be certain of the source of the $\mathrm{Pb}$ ore, but it would probably have been from a mine not too distant. Thus, we argue that the high $\mathrm{Pb}$ ratios are reasonably attributable to processing of Balmat mine ore in Jamaica Bay.

Because there was no correlation between total dissolved $\mathrm{Pb}$ and $\mathrm{Ra}$ (not shown) as was observed for $\mathrm{Co}, \mathrm{Zn}, \mathrm{Ni}$, and Fe (discussed below), SGD probably does not represent a significant source of total $\mathrm{Pb}$ to Jamaica Bay. However, the $\mathrm{Pb}$ isotope data suggest that SGD supplies a small, but significant, amount of isotopically distinct $\mathrm{Pb}$. These data suggest that $\mathrm{Pb}$ isotopes may provide a useful tracer of $\mathrm{SGD}$ in locations where subsurface $\mathrm{Pb}$ contamination is present and warrant further investigation.

\section{The Effect of SGD on Dissolved Metals in Jamaica Bay}

It has been previously shown that SGD supplies most of the substantial excess Ra observed in the Jamaica Bay water

Fig. 8 a $\mathrm{Pb}$ isotope ratio plot for JB water column samples. Solid square symbols indicate October 2004 cruise, hollow triangles indicate April 2006 cruise, crosses indicate wastewater samples, and asterisks indicate sewage estuary samples. The arrows indicate highsalinity samples collected during both cruises at the JB inlet (see also Fig. 2). b JB water column $\mathrm{Pb}$ isotopes plotted with potential sources from the local watershed and region. References for $\mathrm{Pb}$ sources include: Hudson sediments and Balmat $\mathrm{Pb}$ mine (Chillrud et al. 2003), atmospheric (Marcantonio et al. 2002), and sandstones/shales (Bock et al. 1998)

values found in sandstones and shales in the upper Hudson River watershed (Bock et al. 1998). Therefore, the $\mathrm{Pb}$ in the wastewater may reflect contamination from runoff (collected by storm drains) or water piped to NYC from upstate aquifers (Houghton et al. 2005).

The high endmember ratios measured in the water column appear to reflect $\mathrm{Pb}$ contamination originating from a mine in upstate NY. Chillrud et al. (2003) measured $\mathrm{Pb}$ ratios in sediment cores from the upper Hudson River and found a wide range of ratios that corresponded to different $\mathrm{Pb}$ sources during changing decades. A particularly anomalous sediment layer was found that had the high ratios shown in Fig. 8b; to explain these ratios, Chillrud et al. (2003) argued that the ratios represented $\mathrm{Pb}$ contaminacolumn (Beck et al. 2007a). This input of Ra suggests that SGD may represent a similar source for other dissolved groundwater constituents, particularly cations (Moore 1999). We have observed groundwater seepage occurring on the beachface at both the Canarsie Pier and Canarsie Pol

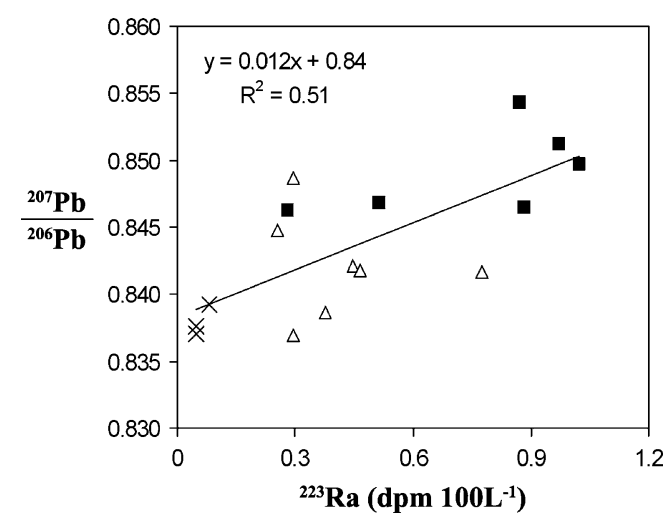

Fig. $9207 / 206 \mathrm{~Pb}$ ratio vs ${ }^{223} \mathrm{Ra}$ in water column and effluent samples. Symbols as in Fig. 2. Note that two samples from the October 2004 cruise that are shown in Fig. 10 are not included because $\mathrm{Ra}$ data do not exist for those samples. The solid line represents a linear regression of all the data shown. Ra data from Beck et al. (2007a) 
locations. In fact, at the seepage site on Canarsie Pol, an orange-red precipitate was visible on the sediment surface. Shallow excavation revealed that the orange color was only on the surface, and subsurface sands were a gray color. This visual evidence suggests that the groundwater seep was transporting reduced Fe species, which then precipitated out of solution upon entering an oxic environment, similar to the "Iron Curtain" described by Charette and Sholkovitz (2002). This provides anecdotal evidence for the occurrence of SGD-driven trace metal inputs to Jamaica Bay, and the significance of these inputs is discussed below.

\section{Molybdenum (Mo)}

The effect of SGD is evident in the dissolved Mo distribution in the Jamaica Bay water column, although in this case, it represents a sink, not a source, as has been observed in another estuary (Dalai et al. 2005). Given that Mo behaves conservatively in oxic seawater and has a relatively constant concentration of approximately $110 \mathrm{nM}$ (Collier 1985), the observed Mo distribution in Jamaica Bay waters cannot be explained by other than a removal mechanism. In other words, if the oceanic concentration is fixed, the observed concentrations in surface waters of the bay cannot be explained by variations in the wastewater endmember, as was argued for the other metals (see above). Furthermore, the conservative behavior of Mo in the sewage estuary (Fig. 3b) and at high salinities (Fig. 2b) suggests that Mo is mixing conservatively, and an independent process is responsible for its removal within the bay.
The pattern of Mo depletion observed for the three cruises matches that of the Ra-estimated SGD flux (September $>$ October $>$ April; Beck et al. 2007a). This SGD comprises primarily recirculated seawater, and Mo depletion in the water column is apparently the result of Mo scavenging/precipitation as oxic seawater is recirculated through suboxic, reducing permeable sediments. Indeed, Mo concentrations measured in shallow groundwater profiles in JB show nearly quantitative removal at salinities greater than 20 (Fig. 6b). Thus, substantial recirculation of seawater through the bay floor extracts Mo while leaving salinity unchanged.

\section{Zinc (Zn), Cobalt (Co), Iron (Fe), and Nickel (Ni)}

Dissolved $\mathrm{Zn}, \mathrm{Co}, \mathrm{Fe}$, and Ni were all enriched in surficial groundwater relative to surface water concentrations (Fig. 5), suggesting that SGD may be a source of these metals to the water column. Indeed, covariation of $\mathrm{Co}, \mathrm{Zn}$, $\mathrm{Ni}$, and $\mathrm{Fe}$ with ${ }^{223} \mathrm{Ra}$ indicates an input from benthic sources (Fig. 10). This covariation was only observed in bottom water samples during the October 2004 cruise, likely resulting from the strong vertical stratification associated with summer conditions that effectively isolated bottom waters from the sewage-impacted surface waters. Such stratification was not evident during the spring cruise. Because diffusion of Ra during summer could only support 4-9\% of the observed inventory (Beck et al. 2007a), most of the benthic trace metal input is also probably due to advection of porewater.
Fig. 10 Covariation of dissolved metals and ${ }^{223} \mathrm{Ra}$. Only bottom water samples from the October 2004 cruise are shown. The solid line represents a linear regression of the data. The regression line of the Fe data does not include the $145 \mathrm{nM}$ point. Ra data from Beck et al. (2007a)
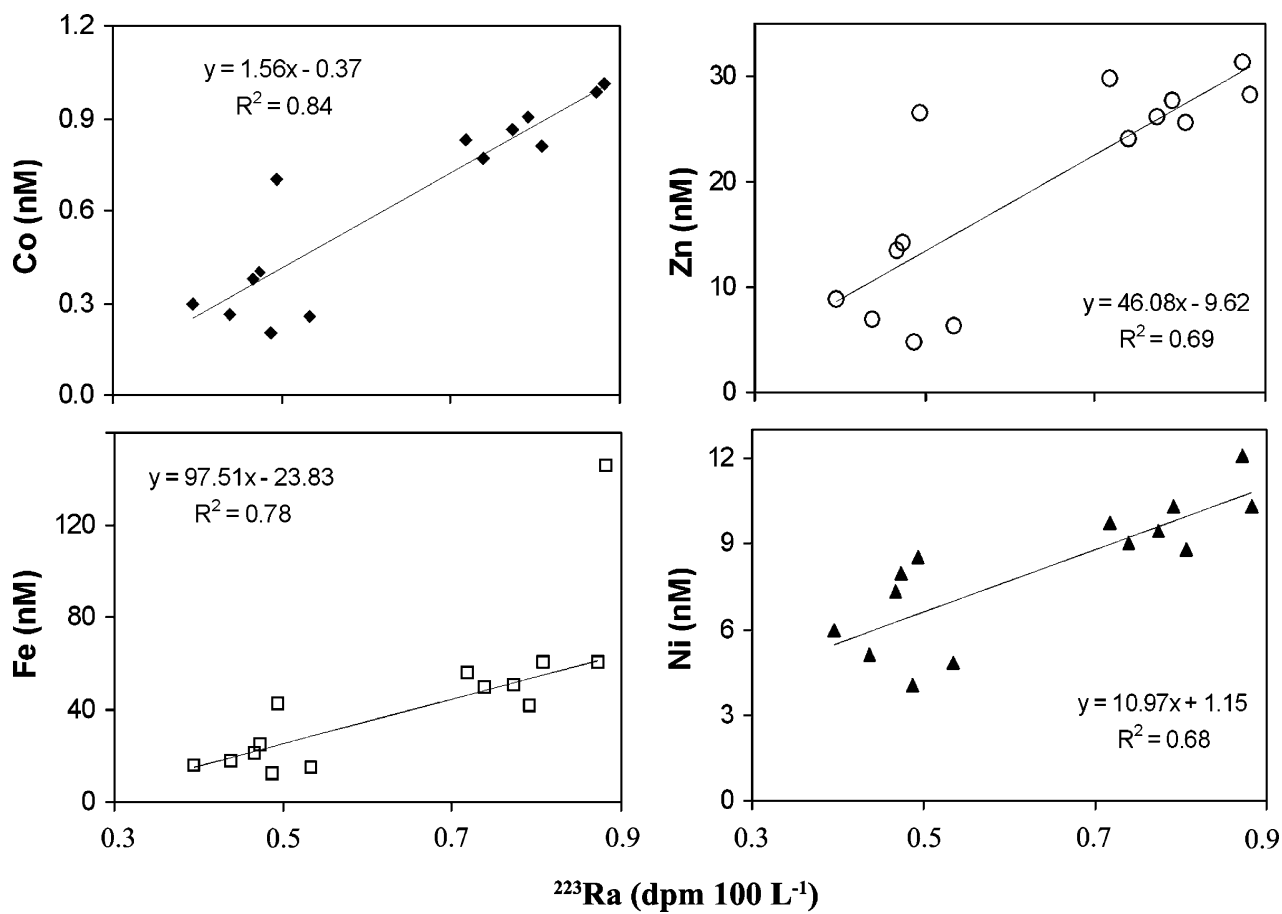


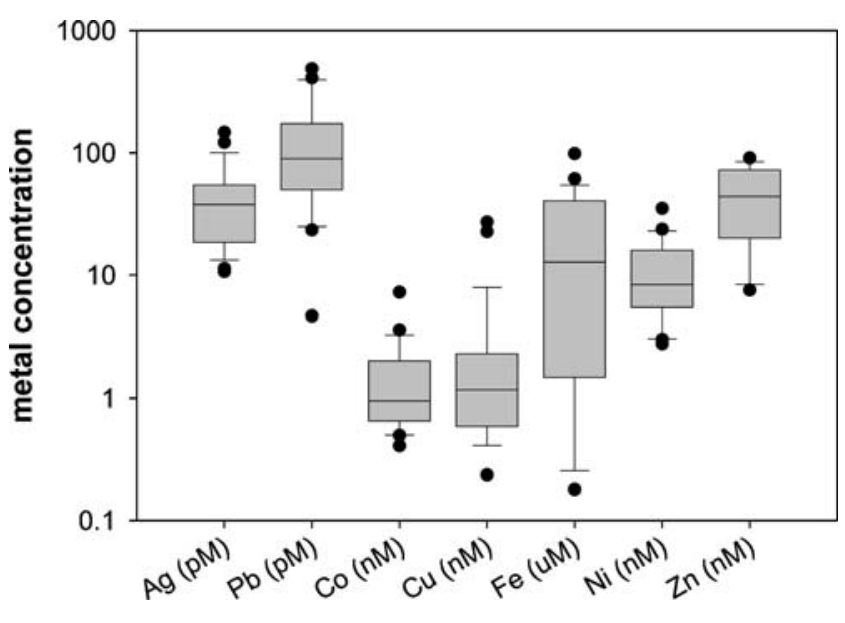

Fig. 11 Box-and-whisker plot of metal concentrations measured in Jamaica Bay groundwaters. The horizontal line within each box is the median, and the boundaries of the boxes indicate the 25th and 75th percentiles. Whiskers above and below the boxes indicate the 10th and 90th percentiles. Filled circles identify outlying points

\section{Quantitative Estimates of Dissolved Metal Flux Due to SGD}

Using the dissolved metal concentrations observed in the subterranean estuary (i.e., Figs. 6 and 11), one can theoretically calculate SGD-associated metal fluxes. However, the variability in metal concentrations observed with depth in the permeable sediments makes it difficult to identify what value best represents the SGD endmember. For some metals (e.g., $\mathrm{Fe}$ and $\mathrm{Pb}$, Fig. 6), the linear distribution with chloride in the most saline porewater samples suggests that a reasonable "effective zero-salinity endmember" can be estimated (e.g., Charette and Sholkovitz 2006; Beck et al. 2007b; Bone et al. 2007). However, for most of the metals, scatter in the data makes it less clear how to calculate a good SGD endmember. In this case, use of an average concentration presumably serves best (Shaw et al. 1998; Charette and Buessler 2004).
The mass flux of trace metals in SGD is then calculated as the product of median metal concentration $\left(\mathrm{mol} \mathrm{L}^{-1}\right)$ and Raestimated SGD flux $\left(\mathrm{L} \mathrm{day}^{-1}\right)$. Median metal concentrations are shown in Table 2. Using the SGD water fluxes reported in Beck et al. (2007a), metal fluxes can be calculated for the different cruises; these are also shown in Table 2. Fluxes into Jamaica Bay range from $0.06 \mathrm{~mol} \mathrm{day}^{-1}$ for $\mathrm{Ag}$ to $1.6 \times$ $10^{5} \mathrm{~mol} \mathrm{day}^{-1}$ for $\mathrm{Fe}$. Given the large scatter in the groundwater metal data (Fig. 11), it is worth examining the variability in the flux estimate using different endmember concentrations. The first and third quartile values (i.e., lower and upper bounds of the boxes in Fig. 11) are a good starting point, and flux estimates using these as endmember concentrations are shown in Table 2. Generally, most midrange dissolved metal concentrations in the groundwater did not vary too greatly, and fluxes calculated with different endmember values were mostly within a factor of two or three. The exception, $\mathrm{Fe}$, had a very wide range of concentrations in the porewater.

To put these fluxes into perspective, we compare them to the wastewater metal fluxes. Using $C^{*}$ (Table 1) for dissolved metal concentrations in wastewater, and the combined volume discharge of the four major treatment plants $\left(7.46 \times 10^{8} \mathrm{~L} \mathrm{day}^{-1}\right)$, the flux can be calculated (Table 2). Although the metal concentrations are much higher in wastewater than in the groundwater, the much smaller amount of wastewater discharge compared to SGD results in comparable magnitudes between the two fluxes. In fact, this approach suggests that SGD is responsible for dissolved Co and Ni fluxes that exceed WWTP input for those two metals. Fluxes of $\mathrm{Ag}$ and $\mathrm{Zn}$ are comparable between SGD and wastewater, and the $\mathrm{Pb}, \mathrm{Cu}$, and $\mathrm{Fe}$ fluxes are markedly lower in SGD than wastewater. The substantial relative fluxes we estimate for these metals in the Jamaica Bay setting are consistent with reports for different metal fluxes elsewhere (Charette and Buesseler

Table 2 Median groundwater metal concentrations, and estimated metal fluxes

\begin{tabular}{|c|c|c|c|c|c|c|c|}
\hline & $\mathrm{Ag}$ & $\mathrm{Pb}$ & Co & $\mathrm{Cu}$ & $\mathrm{Fe}$ & $\mathrm{Ni}$ & $\mathrm{Zn}$ \\
\hline \multicolumn{8}{|c|}{ Median dissolved concentration in groundwater (nM) } \\
\hline & 0.038 & 0.089 & 0.95 & 1.2 & 1300 & 8.4 & 44 \\
\hline \multicolumn{8}{|c|}{ SGD dissolved metal flux (mol d ${ }^{-1}$, except Fe $\left.1000 \mathrm{~mol} \mathrm{~d}^{-1}\right)$} \\
\hline Sept 04 & $0.28(0.14,0.38)$ & $0.7(0.4,1.2)$ & $7(5,14)$ & $9(4,16)$ & $93(12,289)$ & $61(40,112)$ & $321(172,524)$ \\
\hline Oct 04 & $0.16(0.08,0.22)$ & $0.4(0.2,0.7)$ & $4(3,8)$ & $5(3,9)$ & $55(7,170)$ & $36(24,66)$ & $189(101,309)$ \\
\hline Sept 05 & $0.20(0.10,0.27)$ & $0.5(0.3,0.9)$ & $5(3,10)$ & $6(3,12)$ & $68(9,210)$ & $44(29,81)$ & $233(125,380)$ \\
\hline Apr 06 & $0.06(0.03,0.08)$ & $0.14(0.08,0.3)$ & $2(1,3)$ & $2(1,3)$ & $20(3,63)$ & $13(9,24)$ & $70(38,115)$ \\
\hline \multicolumn{8}{|c|}{ Wastewater dissolved metal flux ( $\mathrm{mol} \mathrm{d}^{-1}$, except Fe $1000 \mathrm{~mol} \mathrm{~d}^{-1}$ ) } \\
\hline & 0.15 & 1.5 & 2.1 & 38 & 550 & 20 & 175 \\
\hline
\end{tabular}

Estimates of metal flux associated with SGD are calculated using these metal concentrations and Ra-estimated SGD flux (Beck et al. 2007a). Flux values in parentheses indicate fluxes calculated using concentrations at the first and third quartiles: median (first quartile, third quartile), to illustrate the range of reasonable fluxes calculated using the measured concentrations in groundwater (see text and Fig. 11). The wastewater metal flux is calculated using $C^{*}$ from Table 1 and the average daily wastewater discharge. 
2004; Bone et al. 2007), and further demonstrates the importance of SGD to chemical budgets in coastal waters.

We should note here that the WWTP metal fluxes we calculate for $\mathrm{Cu}, \mathrm{Pb}, \mathrm{Ni}$, and $\mathrm{Zn}$ (the only common metals available for comparison) are lower than those calculated by Seidemann (1991), by factors of 30, 7, 82, and 10, respectively. Given that the WWTP discharge volumes used by Seidemann (originating from a 1984 report) are comparable to ours, the discrepancy must be one of effluent metal concentrations. We cannot identify whether our effluent measurements are lower because they were filtered (filtration is not mentioned in Seidemann 1991) or because improved wastewater treatment has resulted in a substantial decline in effluent metal concentrations since 1984. The latter argument is partly supported by the flux data reported by Bopp et al. (1993), which indicates that metal inputs to Jamaica Bay seem to be decreasing over the past several decades.

Although it seems profound that SGD can deliver as substantial a trace metal load to Jamaica Bay as treated wastewater, it seems unlikely given the obvious wastewater source. The distributions of dissolved metals in the water column show clearly that wastewater is the dominant input. Although the trends observed in this study suggest that SGD represents a substantial input of metals to Jamaica Bay, many of the elements shown in Fig. 5 show lowest concentrations in the saline porewater near the sedimentwater interface. Assuming homogeneous vertical flow, this suggests that metals are being removed from the porewater as it flows toward the surface. However, total removal would disallow the trends between metals and Ra observed in Fig. 10. Therefore, there must be a mechanism by which trace metals in the groundwater can escape the sediment surface-perhaps through channelized, preferential flowpaths that are not captured by the porewater sampling technique used here. Future research should examine this problem more closely; more accurate estimates of the dissolved metal endmember concentration in SGD are required if metal fluxes are to be better constrained.

\section{Summary and Conclusions}

This study provides some of the first measurements of dissolved trace metals in Jamaica Bay, NY. Metals levels in the Jamaica Bay water column are highly elevated relative to offshore waters and clearly reflect contamination due primarily to wastewater input. The elevated metals levels observed in Jamaica Bay are comparable to other urban estuaries in the USA.

The trends observed for dissolved trace metals within the mixing zone between wastewater and bay surface water indicate that $\mathrm{Ag}, \mathrm{Pb}, \mathrm{Co}$, and $\mathrm{Zn}$ are highly removed from the dissolved phase relative to conservative mixing; $\mathrm{Ni}$ and $\mathrm{Cu}$ show removal to a lesser degree, and $\mathrm{Mo}$ and $\mathrm{Fe}$ exhibit approximately conservative behavior. Most metals show further removal within the bay water column. Association with $\mathrm{DOC}$ was only observed for $\mathrm{Cu}, \mathrm{Zn}$, and $\mathrm{Ni}$.

The influence of SGD on trace metal distributions within the bay was observed for several metals. The pattern of Mo depletion in the water column matched the variation in SGD previously reported for Jamaica Bay. The nonconservative removal of Mo observed in shallow groundwater suggests that seawater recirculation through permeable, anoxic sediments acted as a sink for dissolved Mo. In contrast, other metals $(\mathrm{Cu}, \mathrm{Ni}, \mathrm{Zn}$, and $\mathrm{Fe}$ ) showed positive covariation with dissolved $\mathrm{Ra}$ in bottom waters when the water column was stratified, suggesting an SGD source.

The trends observed for stable $\mathrm{Pb}$ isotope ratios in the water column could largely be explained by mixing between wastewater and coastal ocean waters, but samples that were more radiogenic required a third endmember. Although the lack of relationship between total dissolved $\mathrm{Pb}$ and $\mathrm{Ra}$ suggested that SGD did not supply a significant amount of total $\mathrm{Pb}$, covariation between $\mathrm{Pb}$ isotope ratios and dissolved ${ }^{223} \mathrm{Ra}$ did indicate that SGD was the source of the radiogenic $\mathrm{Pb}$.

Although wastewater input was probably the dominant source of trace metal contamination to Jamaica Bay, the effect of SGD on dissolved trace metal distributions was also observed. This suggests that SGD may play an even more significant role in trace metal cycling in coastal regions that are less obviously impacted by anthropogenic activities. Certainly, taken with previous work, the results of the current study corroborate the role of SGD as a globally prevalent, major source of trace metals to coastal waters.

SGD-derived trace metal fluxes were calculated simply as the product of median groundwater metal concentrations and Ra-estimated SGD water flux. Flux calculations using higher and lower endmember metal concentrations indicated that estimated fluxes generally varied by a factor of only two or three but, as for Fe, could be as high as an order of magnitude. With this approach, SGD appeared to represent a dissolved trace metal flux of equal proportion to wastewater inputs. The clear evidence of chemical reactions occurring in the subterranean estuary, and the dominant signal of wastewater-derived metals in the water column, indicate that this method of estimating fluxes probably does not accurately represent the real SGD metal flux. Methods for directly collecting and measuring the groundwater as it crosses the sediment-water interface are needed to better constrain the true dissolved metal flux associated with SGD. 


\section{References}

Aller, R.C. 1994. The sedimentary Mn cycle in Long Island SoundIts role as intermediate oxidant and the influence of bioturbation, $\mathrm{O} 2$, and $\mathrm{C}$ (org) flux on diagenetic reaction balances. Journal of Marine Research 52: 259-295.

Beck, A.J., J.P. Rapaglia, J.K. Cochran, and H.J. Bokuniewicz. 2007a. Radium mass-balance in Jamaica Bay, NY: Evidence for a substantial flux of submarine groundwater. Marine Chemistry 106: 419-441.

Beck, A.J., Y. Tsukamoto, A. Tovar-Sanchez, M. Huerta-Diaz, H.J. Bokuniewicz, and S.A. Sanudo-Wilhelmy. 2007b. Importance of geochemical transformations in determining submarine groundwater discharge-derived trace metal and nutrient fluxes. Applied Geochemistry 22: 477-490.

Benner, R., and M. Strom. 1993. A critical evaluation of the analytical blank associated with DOC measurements by high temperature catalytic oxidation. Marine Chemistry 41: 153-160.

Benotti, M., 2006. Occurrence and fate of pharmaceuticals in wastewater-impacted environments using HPLC-TOF-MS. Ph. D. dissertation. Stony Brook University. 324 p.

Benotti M.J., P.E. Misut, M. Abbene, and S.A. Terracciano. 2006. Historic Nitrogen Loading in Jamaica Bay, Long Island, New York: predevelopment to 2005. USGS Open File Report SIR 2007-5051.

Berelson, W., J. McManus, K. Coale, et al. 2003. A time series of benthic flux measurements from Monterey Bay, CA. Continental Shelf Research 23: 457-481.

Black, F.R. 1981. Jamaica Bay-A history. Cultural Resource Study 3. Washington D.C.: Division of Cultural Resources, North Atlantic Regional Office, National Parks Service of the US Dept. of the Interior.

Bock, B., S.M. McLennan, and G.N. Hanson. 1998. Geochemistry and provenance of the Middle Ordovician Austin Glen Member (Normanskill Formation) and the Taconian Orogeny in New England. Sedimentology 45: 635-655.

Bone, S.E., M.A. Charette, C.H. Lamborg, and M.E. Gonneea. 2007. Has submarine groundwater discharge been overlooked as a source of mercury to coastal waters? Environmental Science and Technology 41(9): 3090-3095.

Bopp, R.F., H.J. Simpson, S.N. Chillrud, and D.W. Robinson. 1993. Sediment-derived chronologies of persistent contaminants in Jamaica Bay, New York. Estuaries 16(3B): 608-616.

Boyle, E., R. Collier, A.T. Dengler, J.M. Edmond, A.C. Ng, and R.F. Stall. 1974. On the chemical mass-balance in estuaries. Geochimica et Cosmochimica Acta 38: 1719-1728.

Bray, J.T., O.P. Bricker, and B.N. Troup. 1973. Phosphate in interstitial waters of anoxic sediments: Oxidation effects during sampling procedure. Science 180(4093): 1362-1364.

Bruland, K.W., K.H. Coale, and L. Mart. 1985. Analysis of seawater for dissolved cadmium, copper and lead: An intercomparison of voltammetric and atomic absorption methods. Marine Chemistry 17: $285-300$.

Buck, N.J., C.J. Gobler, and S.A. Sañudo-Wilhelmy. 2005. Dissolved trace element concentrations in the east River-long Island Sound System: Relative importance of autochthonous versus allochthonous sources. Environmental Science \& Technology 39: 3528-3537.

Charette, M.A., and M.C. Allen. 2006. Precision groundwater sampling in coastal aquifers using a direct push shielded screen well-point system. Groundwater Monitoring \& Remediation 26 (2): 87-93.

Charette, M.A., and K.O. Buesseler. 2004. Submarine groundwater discharge of nutrients and copper to an urban subestuary of Chesapeake bay (Elizabeth River). Limnology and Oceanography 49(2): 376-385.
Charette, M.A., and E.R. Sholkovitz. 2002. Oxidative precipitation of groundwater-derived ferrous iron in the subterranean estuary of a coastal bay. Geophysical Research Letters 29(10), doi:10.1029/ 2001GL014512.

Charette, M.A., and E.R. Sholkovitz. 2006. Trace element cycling in a subterranean estuary: Part 2. Geochemistry of the pore water. Geochimica et Cosmochimica Acta 70(4): 811-826.

Chillrud, S.N., S. Hemming, E.L. Shuster, H.J. Simpson, R.F. Bopp, J. M. Ross, D.C. Pederson, D.A. Chaky, L.-R. Tolley, and F. Estabrooks. 2003. Stable lead isotopes, contaminant metals, and radionuclides in upper Hudson River sediment cores: implications for improved time stratigraphy and transport processes. Chemical Geology 199: 53-70.

Cochran, J.K., N.H. Landman, K.K. Turekian, A. Michard, and D.P. Schrag. 2003. Paleoceanography of the Late Cretaceous (Maastrichtian) Western Interior Seaway of North America: evidence from Sr and O isotopes. Palaeogeography, Palaeoclimatology, Palaeoecology 191: 45-64.

Cochran, J.K., H. Feng, D. Amiel, and A. Beck. 2006. Natural radionuclides as tracers of coastal biogeochemical processes. Journal of Geochemical Exploration 88: 376-379.

Collier, R.W. 1985. Molybdenum in the Northeast Pacific Ocean. Limnology and Oceanography 30: 1351-1353.

Dalai, T.K., K. Nishimura, and Y. Nozaki. 2005. Geochemistry of molybdenum in the Chao Phraya River estuary, Thailand: Role of suboxic diagenesis and porewater transport. Chemical Geology 218: $189-202$.

Engelbright, S. 1975. Jamaica Bay: A case study of geo-environmental stress. NY State Geological Assn. Handbook, 47th Annual Meeting, Hofstra University.

Ferguson, P.L., C.R. Iden, and B.J. Brownawell. 2001. Distribution and fate of alkylphenol ethoxylate metabolites in a sewageimpacted urban estuary. Environmental Science \& Technology 35: 2428-2435.

Flegal, A.R., G.J. Smith, G.A. Gill, S.A. Sañudo-Wilhelmy, and L.C. D. Anderson. 1991. Dissolved trace element cycles in the San Francisco Bay estuary. Marine Chemistry 36: 329-363.

Froelich, P.N., G.P. Klinkhammer, M.L. Bender, N.A. Luedtke, G.R. Heath, D. Cullen, and P. Dauphin. 1979. Early oxidation of organic matter in pelagic sediments of the eastern equatorial Atlantic: Suboxic diagenesis. Geochimica et Cosmochimica Acta 43: 1075-1090.

Gobeil, C., B. Rondeau, and L. Beaudin. 2005. Contribution of municipal effluents to metal fluxes in the St. Lawrence River. Environmental Science \& Technology 39: 456-464.

Hartig, E.K., V. Gornitz, A. Kolker, F. Mushacke, and D. Fallon. 2002. Anthropogenic and climate-change impacts on salt marshes of Jamaica Bay, New York City. Wetlands 22(1): 71-89.

Houghton, R., A. Gordon, and B. Huber. 2005. Dye tracer experiments in Jamaica Bay. In: Integrated Reconnaissance of the Physical and Biogeochemical Characteristics of Jamaica Bay: Initial Activity Phase. A Coordinated Program of the Gateway National Recreational Area and the Columbia Earth Institute. p51-53.

Luoma, S.N., and D.J.H. Phillips. 1988. Distribution, variability and impacts of trace elements in San Francisco Bay. Marine Pollution Bulletin 19(9): 413-425.

Lyons, W.B., H.E. Gaudette, and G.M. Smith. 1979. Porewater sampling in anoxic carbonate sediments: oxidation artefacts. Nature 277: 48-49.

Ma, H., H.E. Allen, and Y. Yin. 2001. Characterization of isolated fractions of dissolved organic matter from natural waters and a wastewater effluent. Water Research 35(4): 985-996.

Marcantonio, F., A. Zimmerman, Y. Xu, and E. Canuel. 2002. A Pb isotope record of mid-Atlantic US atmospheric $\mathrm{Pb}$ emissions in Chesapeake Bay sediments. Marine Chemistry 77: 123-132. 
Misut, P.E., and C.I., Voss. 2004. Simulation of subsea discharge to Jamaica Bay in New York City with a three-dimensional, variable density, finite-element model. In Finite element models, MODFLOW, and more: Solving groundwater problems, eds. Koval-HrkalBruthans, p. 391-394.

Moore, W.S. 1999. The subterranean estuary: a reaction zone of ground water and sea water. Marine Chemistry 65(1-2): 111-125.

Paulsen, A.J. 2005. Tracing water and suspended matter in Raritan and Lower New York Bays using dissolved and particulate elemental concentrations. Marine Chemistry 97: 60-77.

Ramondetta, P.J., and W.H. Harris. 1978. Heavy metals distribution in Jamaica Bay sediments. Environmental Geology 2(3): 145149.

Sañudo-Wilhelmy, S.A., and A.R. Flegal. 1992. Anthropogenic silver in the Southern California Bight: A new tracer of sewage in coastal waters. Environmental Science \& Technology 26: 21472151.

Sañudo-Wilhelmy, S.A., and A.R. Flegal. 1994. Temporal variations in lead concentrations and isotopic composition in the Southern California Bight. Geochimica et Cosmochimica Acta 58: 33153320.

Sañudo-Wilhelmy, S.A., and G.A. Gill. 1999. Policy analysis. The impact of the clean water act on the levels of toxic metals in urban estuaries: The hudson river estuary revisited. Environmental Science and Technology 33: 3477-3481.

Sañudo-Wilhelmy, S.A., A. Tovar-Sanchez, N. Fisher, and A.R. Flegal. 2004. Examining dissolved toxic metals in U.S. estuaries. Environmental Science and Technology 38: 34A-38A

Sedlak, D.L., J.T. Phinney, and W.W. Bedsworth. 1997. Strongly complexed $\mathrm{Cu}$ and $\mathrm{Ni}$ in wastewater effluents and surface runoff. Environmental Science and Technology 31(10): 3010-3016.

Seidemann, D.E. 1991. Metal pollution in sediments of Jamaica Bay, New York, USA-An urban estuary. Environmental Management 15(1): 73-81.
Shafer, M.M., S.R. Hoffmann, J.T. Overdier, and D.E. Armstrong. 2004. Physical and kinetic speciation of copper and zinc in three geochemically contrasting marine estuaries. Environmental Science and Technology 38: 3810-3819.

Shaw, T.J., J.M. Gieskes, and R.A. Jahnke. 1990. Early diagenesis in differing depositional environments: The response of transition metals in pore water. Geochimica et Cosmochimica Acta 54: 1233-1246.

Shaw, T.J., W.S. Moore, J. Kloepfer, and M.A. Sochaski. 1998. The flux of barium to the coastal waters of the southeastern USA: The importance of submarine groundwater discharge. Geochimica et Cosmochimica Acta 62(18): 3047-3054.

Sholkovitz, E.R., E.A. Boyle, and N.B. Price. 1978. The removal of dissolved humic acids and iron during estuarine mixing. Earth and Planetary Science Letters 40: 130-136.

Stukas, V.J., and C.S. Wong. 1980. Stable lead isotopes as a tracer in coastal waters. Science 194: 179-183.

Sugimura, Y., and Y. Suzuki. 1988. A high temperature catalytic oxidation method for the determination of nonvolatile dissolved organic carbon in seawater by direct injection of a liquid sample. Marine Chemistry 24: 105-131.

Swanson, R.L., A.S. West-Valle, and C.J. Decker. 1992. Recreation vs. Waste disposal: The use and management of Jamaica Bay. Long Island History Journal 5(1): 21-24.

Ternes, T.A., and R. Hirsch. 2000. Occurrence and behavior of X-ray contrast media in sewage facilities and the aquatic environment. Environmental Science and Technology 34: 2741-2748.

US EPA, 1995. National Water Quality Inventory; 1994 Report to Congress; EPA/841/R-95/005. U.S. Environmental Protection Agency. Washington, D.C.

Windom, H.L., W.S. Moore, L.F.H. Niencheski, and R.A. Jahnke. 2006. Submarine groundwater discharge: a large, previously unrecognized source of dissolved iron to the South Atlantic Ocean. Marine Chemistry 102: 252-266. 